\title{
Differential detection of key enzymes of polyaromatic-hydrocarbon-degrading bacteria using PCR and gene probes
}

\author{
Svenja Meyer, ${ }^{1}$ Ralf Moser, ${ }^{2}$ Alexander Neef, ${ }^{1}$ Ulf Stahl ${ }^{2}$ \\ and Peter Kämpfer ${ }^{1}$ \\ Author for correspondence: Svenja Meyer. Tel: +496419937363 . Fax: +496419937359. \\ e-mail: Svenja.S.Meyer@agrar.uni-giessen.de
}

1 Justus-Liebig-University Giessen, Institute of Applied Microbiology, Senckenbergstraße 3 , D-35390 Giessen, Germany

2 University of Technology Berlin, Institute of Biotechnology, Department of Microbiology and Genetics, Gustav-MeyerAllee 25, D-13355 Berlin, Germany

\begin{abstract}
Bacteria with ability to degrade polyaromatic hydrocarbons (PAHs), isolated from wastewater and soil samples, were investigated for their taxonomic, physiological and genetic diversity. Eighteen isolates able to metabolize naphthalene or phenanthrene as sole carbon source were taxonomically affiliated to different subclasses of the Proteobacteria (Sphingomonas spp., Acidovorax spp., Comamonas spp. and Pseudomonas spp.) and to phyla of Gram-positive bacteria with low and high DNA G+C content (Paenibacillus sp. and Rhodococcus Spp., respectively). Representatives of the genera Pseudomonas and Sphingomonas formed a remarkably high fraction of these isolates; 9 out of 18 strains belonged to these groups. Tests for enzyme activities showed that the majority of the isolates growing with PAHs as sole sources of carbon and energy had an active catechol 2,3-dioxygenase (C230). C230 specific activities were very diverse, ranging from 0.1 to $650 \mathrm{mU}$ (mg protein $)^{-1}$. Pseudomonas and Sphingomonas strains showed considerably higher activities than the other isolates. All PAH degraders were examined for the presence of an initial PAH dioxygenase and C230, which catalyse key steps of PAH degradation, by PCR amplification of gene fragments and subsequent hybridization. PCR primers and internal oligonucleotide probes were developed for the specific detection of the genes of Pseudomonas and Sphingomonas strains.
\end{abstract}

Keywords: PAH degradation, initial PAH dioxygenase, catechol 2,3-dioxygenase, PCRbased approach, DNA probes

\section{INTRODUCTION}

Some fungi and bacteria are capable of oxidizing polyaromatic hydrocarbons ( $\mathrm{PAHs}$ ). There are three types of microbial $\mathrm{PAH}$ degradation: complete mineralization, co-metabolic transformation and nonspecific oxidation (Cerniglia, 1984). To effectively decontaminate polluted sites it is desirable that there is complete mineralization to prevent accumulation of metabolites. Complete mineralization of different PAHs has been described for some bacterial strains belonging to different phylogenetic groups (Cerniglia \& Heitkamp, 1990; Cerniglia, 1992). The biochemical pathways of

Abbreviations: C230, catechol 2,3-dioxygenase; FAME, fatty acid methyl ester; PAH, polyaromatic hydrocarbon. bacterial degradation of low-molecular-mass PAHs such as naphthalene, phenanthrene and anthracene have been elucidated in detail (Cerniglia, 1992). The genus Pseudomonas has been the subject of much research as regards its ability to degrade PAHs (Foght \& Westlake, 1988; Kiyohara et al., 1994; Johnsen et al., 1996).

The first step in the aerobic degradation of polyaromatic compounds is dependent on the presence of a multicomponent enzyme system, the initial PAH dioxygenase (EC 1.14.12.12), catalysing the hydroxylation of the substrate to the corresponding cis-dihydrodiol (Ensley et al., 1982; Simon et al., 1993; Williams \& Sayers, 1994). Extradiol cleavage and subsequent degradation with the stepwise removal of aromatic rings completes the upper pathway finally leading to catechol, one of the central intermediates of PAH degradation. Meta-cleavage of catechol catalysed by catechol 2,3-dioxygenase (C23O; 
EC 1.13.11.2) seems to be the most common pathway in the subsequent steps of PAH degradation (lower pathway) (Houghton \& Shanley, 1994). The four published nucleotide sequences of genes encoding the initial PAH dioxygenase originated from three different Pseudomonas putida strains and one Pseudomonas aeruginosa strain (Simon et al., 1993; Takizawa et al., $1994)$ and are approximately $87-93 \%$ similar. C23O gene sequences for bacteria of the genus Pseudomonas have also been determined (Keil et al., 1985; Ghosal et al., 1987; Bartilson \& Shingler, 1989; Benjamin et al., 1991; Harayama et al., 1991; Ng et al., 1994; Carrington et al., 1994; Herrmann et al., 1995), as well as sequences from degraders of other different genera, such as Ralstonia (Kabisch \& Fortnagel, 1990; Moon et al., 1995; Kukor \& Olsen, 1996), Sphingomonas (Yrjälä et al., 1994; Kim \& Zylstra, 1995) Bacillus and Rhodococcus (Candidus et al., 1994). Protein and nucleotide sequences of the $\mathrm{C} 23 \mathrm{O}$ of most of the examined Pseudomonas and Sphingomonas strains are relatively similar to each other, forming two distinct sequence clusters. Sequences of other bacteria show lower similarity to these two clusters.

On account of the key position of the initial dioxygenase and the $\mathrm{C} 23 \mathrm{O}$ during complete $\mathrm{PAH}$ mineralization, these genes seem to be suitable targets to detect the presence of PAH degradation potential at the DNA level. Genotypic detection could be achieved by PCRbased approaches and hybridization with gene probes. These molecular methods are advantageous when considering the time required for cultivation-dependent isolation of pure cultures. Specific probes and PCR primers could be designed based on existing DNA sequences encoding these enzymes. This approach has already been followed on a limited number of sequences for C23O by Joshi \& Walia (1996) and Wikström et al. (1996). The aim of the present investigation was to isolate bacterial PAH degraders from aquatic and terrestrial sites, to determine their taxonomic affiliation and to characterize them physiologically and genetically with respect to their ability to degrade PAHs.

\section{METHODS}

Bacterial strains. The following reference strains were used in this study: P. putida OUS82 (Kiyohara et al., 1994) and $P$. putida NCIB 9816 (Simon et al., 1993); both are reported to possess an initial dioxygenase. $P$. putida $\mathrm{F} 1$ is reported to possess a toluene dioxygenase but not PAH dioxygenase (Zylstra \& Gibson, 1989). Escherichia coli SURE (Promega), lacking any PAH degradation ability, and P. putida KT2440 (= DSM 6125), described as a strain lacking C23O (Franklin et al., 1981), were used as negative controls for amplification of gene fragments of the initial dioxygenase and $\mathrm{C} 23 \mathrm{O}$, respectively. Further strains described as PAH degraders were also examined: Pseudomonas stutzeri AN11 (kindly provided by R. Rosselló-Mora; Max Planck Institute for Marine Microbiology, Bremen, Germany); Sphingomonas yanoikuyae DSM 6900 (Gibson et al., 1973) and Sphingomonas paucimobilis BA2 (Kästner et al., 1994).
Collection of environmental samples and isolation of PAHdegrading bacteria. Environmental samples for enrichment of PAH-degrading strains were collected in sterilized jars from aquatic and terrestrial sites (Table 1). The samples were transported and stored on ice until further treatment.

Soil samples were prepared as described by Kästner $e t$ al. (1994) within a day of collection. Basal medium $(25 \mathrm{ml})$ supplemented with either $0.05 \%(\mathrm{w} / \mathrm{v})$ crystalline naphthalene or phenanthrene was inoculated with an aliquot of suitable dilutions 0 of the aquatic samples or the soil extracts. The enrichment cultures were incubated aerobically at $25^{\circ} \mathrm{C}$ on a rotary incubator at 180 r.p.m. Following visible growth, aliquots of the cultures were transferred to fresh basal medium, also containing $0.05 \%$ of the PAH. Naphthaleneand phenanthrene-degrading strains were isolated from these enriched cultures by repeated streaking on R2A agar (Oxoid) until individual colonies were obtained.

Identification of PAH-degrading isolates. Cell morphology was determined by phase-contrast microscopy. Oxidase tests were performed as described by the manufacturer (Merck) and Gram-staining was performed using a modified Hucker method (Doetsch, 1981). Typing with rRNA-targeted oligonucleotides was performed for basic phylogenetic affiliation. Fluorescently labelled group- and genus-specific probes were used for hybridization of fixed cells of the investigated strains (Amann et al., 1990). The following rRNA-targeted oligonucleotides were used: EUB, a probe specific for the Bacteria (Stahl et al., 1989); ALF1b, BET42a and GAM42a, specific for members of the alpha-, beta- and gamma-subclasses of the Proteobacteria, respectively (Manz et al., 1992); and HGC69a, specific for Gram-positive bacteria with a high DNA G + C content (Roller et al., 1994). Oligonucleotides PS, PPU (Schleifer et al., 1992), COM1424 and ACI208 (Amann et al., 1996) are specific for most genuine pseudomonads, distinct $P$. putida strains, and the genera Comamonas and Acidovorax, respectively.

Further examination of the isolates was done by physiological tests as reported previously (Kämpfer et al., 1991). Fatty acid methyl ester (FAME) patterns were used as a further marker for identification. Preparation of FAME extracts, gas chromatographic analysis and numerical identification by the MIDI system (Sherlock 2.11) were performed as described previously (Kämpfer et al., 1996).

Determination of naphthalene and phenanthrene mineralization potential. The potential of the isolated bacteria for mineralization of PAHs was examined by gas chromatographically quantifying remaining PAH and simultaneously monitoring bacterial growth in batch cultures. For each tested strain, five airtight flasks were each filled with $10 \mathrm{ml}$ basal medium containing either $0.05 \%$ naphthalene or phenanthrene and were inoculated with approximately $10^{7}$ cells. Cell number was estimated by measuring the optical density at $600 \mathrm{~nm}$. Remaining $\mathrm{PAH}$ in the cultures was extracted by vigorously shaking ( $30 \mathrm{~min}$ ) with $5 \mathrm{ml} \mathrm{n}$-hexane for gas chromatographic analysis. The gas chromatograph HP 6890 was equipped with a flame-ionization detector and a $25 \mathrm{~m}$ capillary column (Ultra 2, cross-linked $5 \%$ phenyl methyl siloxan; Hewlett Packard). Separation procedures were as follows: carrier gas, $\mathrm{H}_{2}$; rate of flow, $0.5 \mathrm{ml} \mathrm{min}{ }^{-1}$; split ratio, $28 \mathrm{ml} \mathrm{min}^{-1}$; injector temperature, $250^{\circ} \mathrm{C}$; detector temperature, $300^{\circ} \mathrm{C}$; column temperature programme, $50-275^{\circ} \mathrm{C}$ at $15^{\circ} \mathrm{C} \mathrm{min}^{-1}$, holding at $275^{\circ} \mathrm{C}$ for $1 \mathrm{~min}$, $275-325^{\circ} \mathrm{C}$ at $20^{\circ} \mathrm{C} \mathrm{min}^{-1}$. Recovery of PAH from the medium 
Table 1. Taxonomic affiliation, capacity for degradation of naphthalene and phenanthrene, and specific activity of C230 of environmental isolates from various sampling sites

\begin{tabular}{|c|c|c|c|c|c|c|c|}
\hline \multirow[t]{2}{*}{ Sampling site } & \multirow[t]{2}{*}{$\begin{array}{c}\text { Isolate } \\
\text { designation }\end{array}$} & \multirow[t]{2}{*}{$\begin{array}{c}\text { Taxonomic } \\
\text { affiliation }\end{array}$} & \multirow{2}{*}{$\begin{array}{l}\text { Degradation of } \\
\text { PAHs in liquid } \\
\text { medium }\end{array}$} & \multicolumn{3}{|c|}{$\begin{array}{l}\text { Degradation of phenanthrene } \\
\text { on solid mediumt }\end{array}$} & \multirow[t]{2}{*}{$\begin{array}{l}\text { Specific activity of } \mathrm{C} 23 \mathrm{O} \\
{\left[\mathrm{mU}(\mathrm{mg} \text { protein })^{-1}\right] \neq}\end{array}$} \\
\hline & & & & Plain & $\begin{array}{l}+0.05 \% \\
\text { salicylate }\end{array}$ & $\begin{array}{c}+10 \% \\
\text { TSB }\end{array}$ & \\
\hline \multirow{14}{*}{$\begin{array}{l}\text { Municipal } \\
\text { wastewater } \\
\text { plant, Giessen, } \\
\text { Germany }\end{array}$} & $\mathrm{E}$ & Acidovorax sp. & $\mathrm{p}$ & + & - & + & $0 \cdot 1(\mathrm{p}, 5 \mathrm{~d})$ \\
\hline & F & $\begin{array}{l}\text { Pseudomonas } \mathrm{sp} . \\
\quad(P . \text { putida }) \mathbb{}\end{array}$ & $\mathrm{n}$ & o & + & + & $20 \cdot 1(\mathrm{n}, 3 \mathrm{~d}) ; 12 \cdot 6(\mathrm{n}, 6 \mathrm{~d})$ \\
\hline & G & $\begin{array}{l}\text { Comamonas sp. } \\
\text { (C. testosteroni) } \mathbb{S}\end{array}$ & $\mathbf{n}$ & + & + & - & $0.6(\mathrm{n}, 5 \mathrm{~d})$ \\
\hline & $\mathrm{H}$ & $\begin{array}{l}\text { Comamonas sp. } \\
\text { (C. testosteroni) } \mathbb{S}\end{array}$ & $\mathrm{n}$ & - & + & + & $0.3(\mathrm{n}, 4 \mathrm{~d}) ; 0.5(\mathrm{n}, 5 \mathrm{~d})$ \\
\hline & L7 & $\begin{array}{l}\text { Pseudomonas } \mathrm{sp} . \\
(P . \text { mendocina }) \mathbb{S}\end{array}$ & $\mathrm{n}$ & - & + & - & $0.6(\mathrm{n}, 3 \mathrm{~d})$ \\
\hline & M7 & $\begin{array}{l}\text { Comamonas sp. } \\
\text { (C. terrigena) } \$\end{array}$ & $\mathrm{n}$ & - & o & - & $0 \cdot 9(\mathrm{n}, 3 \mathrm{~d})$ \\
\hline & $\mathrm{A} 10$ & $\begin{array}{l}\text { Pseudomonas sp. } \\
\quad(P . \text { fluorescens }) \|\end{array}$ & $\mathrm{n}$ & - & + & + & $140(\mathrm{n}, 3 \mathrm{~d})$ \\
\hline & F9 & $\begin{array}{l}\text { Pseudomonas sp. } \\
\text { (P. fluorescens) } \|\end{array}$ & $\mathrm{n}$ & - & + & - & $380(\mathrm{n}, 3 \mathrm{~d})$ \\
\hline & H9 & $\begin{array}{l}\text { Pseudomonas sp. } \\
\text { (P. fluorescens) }\end{array}$ & $\mathbf{n}$ & - & + & + & $270(\mathrm{n}, 3 \mathrm{~d})$ \\
\hline & T9 & $\begin{array}{l}\text { Pseudomonas sp. } \\
\quad(P . \text { fluorescens }) \|\end{array}$ & $\mathrm{n}$ & - & + & $-\mathbf{g}$ & $240(\mathrm{n}, 3 \mathrm{~d})$ \\
\hline & E10 & Acidovorax sp. & $\mathrm{p}$ & o & o & + & $0.5(\mathrm{p}, 5 \mathrm{~d})$ \\
\hline & V10 & Acidovorax sp. & $\mathrm{p}$ & + & + & + & $17(\mathrm{p}, 5 \mathrm{~d})$ \\
\hline & G10 & $\begin{array}{l}\text { Actinomycete } \\
\text { (Rhodococcus } \\
\text { erythropolis) } \mathbb{S}\end{array}$ & n & - & o & - & $0(\mathrm{n}, 5 \mathrm{~d})$ \\
\hline & Y9 & Sphingomonas sp. & $\mathrm{n}, \mathrm{p}$ & + & o & + & $\begin{array}{l}8.9(\mathrm{p}, 3 \mathrm{~d}) ; 100(\mathrm{p}, 4 \mathrm{~d}) \\
\quad 140(\mathrm{p}, 5 \mathrm{~d})\end{array}$ \\
\hline $\begin{array}{l}\text { Waste disposal } \\
\text { site, leakage } \\
\text { water, } \\
\text { Reiskirchen, } \\
\text { Germany }\end{array}$ & E3 & Sphingomonas sp. & $\mathrm{n}, \mathrm{p}$ & + & + & + & $270(\mathrm{p}, 4 \mathrm{~d}) ; 440(\mathrm{p}, 5 \mathrm{~d})$ \\
\hline $\begin{array}{l}\text { Industrial } \\
\text { wastewater } \\
\text { plant, } \\
\text { Frankfurt, } \\
\text { Germany }\end{array}$ & B1 & $\begin{array}{l}\text { Actinomycete } \\
\text { (Rhodococcus } \\
\text { rhodochrous }) \$\end{array}$ & $\mathrm{n}$ & o & + & - & $0(\mathrm{n}, 5 \mathrm{~d})$ \\
\hline $\begin{array}{l}\text { Soil from } \\
\text { parking } \\
\text { place, Giessen, } \\
\text { Germany }\end{array}$ & $\mathrm{C} 4$ & $\begin{array}{l}\text { Pseudomonas } \mathrm{sp} . \\
\quad(P . \text { fluorescens }) \|\end{array}$ & $\mathrm{n}, \mathrm{p}$ & o & + & + & $240(\mathrm{n}, 3 \mathrm{~d})$ \\
\hline $\begin{array}{l}\text { Tar oil } \\
\text { contaminated } \\
\text { soil, Hulin, } \\
\text { Czech Republic }\end{array}$ & 3 & Paenibacillus sp. & $\mathrm{n}, \mathrm{p}$ & - & o & $\circ$ & $0(\mathrm{n}, 5 \mathrm{~d})$ \\
\hline
\end{tabular}

*p, Phenanthrene; $\mathrm{n}$, naphthalene.

†TSB, trypticase soy broth; + , formation of colonies surrounded by clear zones; $o$, formation of colonies surrounded by a weak clear zone; -, no formation of colonies observed.

¥ Strains were grown in basal medium (Kästner et al., 1994) supplemented with $0.05 \%$ naphthalene ( $\mathrm{n}$ ) or phenanthrene (p) as sole carbon source for 3-6 d as shown in parentheses. One unit of specific activity is defined as the amount of enzyme that converts $1 \mu \mathrm{mol}$ substrate $\mathrm{min}^{-1}$ (mg protein) $)^{-1}$. The specific activities of the reference strain P. putida OUS82 were 380 ( $\mathrm{n}, 4 \mathrm{~d}$ ) and 650 (p, 4d), and of $S$. yanoikuyae DSM 69000.85 (n, 5d) and $6 \cdot 1(\mathrm{p}, 5 \mathrm{~d})$.

$\$$ Strains could be identified at the species level by FAME (criterion for successful identification at the species level was a score $>0.5$ ) and physiological tests (criterion for successful identification at the species level was a Willcox probability $>0 \cdot 9$ with low scores of taxonomic distances and their standard errors and not more than five characters 'against').

$\|$ Strains could be identified at the species level by physiological tests. (The authentic pseudomonads are very similar with tespect to their fatty acid pattern. The approach with physiological tests was considered more reliable.)

Isolate T9 showed clearing zones with $10 \%$ brain heart infusion instead of TSB. 
Table 2. Sequence and position of PCR primers and internal probes for amplification and detection of dioxygenase sequences

\begin{tabular}{|c|c|c|c|c|}
\hline Primer target/designation & Position & $\begin{array}{l}\text { Annealing } \\
\text { temp. }\left({ }^{\circ} \mathrm{C}\right)\end{array}$ & Sequence $\left(5^{\prime} \text { to } 3^{\prime}\right)^{*}$ & Reference \\
\hline \multicolumn{5}{|l|}{ PAH dioxygenase } \\
\hline ISPGRLE1B & $2505-2521 \dagger$ & 60 & AAAGATCTGTACGGCG & This study \\
\hline ISPGRRI1B & $3385-3404 \dagger$ & 60 & TAAGCCCGGTAGAAACCACG & This study \\
\hline \multicolumn{5}{|l|}{$\mathrm{C} 23 \mathrm{O}$} \\
\hline $23 \mathrm{OF}$ & $207-229 \neq$ & 63 & ATGGATDTDATGGGDTTCAAGGTS & Wikström et al. (1996) \\
\hline $23 \mathrm{OR}$ & $906-928 \ddagger$ & 63 & ACDGTCADGAADCGDTCGTTGAG $\mathbb{Z}$ & Wikström et al. (1996) \\
\hline PSCA23St & $15-34 \ddagger$ & 57 & ATGAAMAAAGGHGTWATGCG & This study \\
\hline PSCA23End\| & $908-928 \ddagger$ & 57 & DGTCADGAADCGDTCGTTGAG & This study \\
\hline SPHCA23St & $28-569$ & 60 & ATGGCWYTGACYGGTGTAMTTCG & This study \\
\hline Probe target/designation & Position & $\begin{array}{l}\text { Stringency of } \\
\text { hybridization }\end{array}$ & Sequence $\left(5^{\prime} \text { to } 3^{\prime}\right)^{*}$ & Reference \\
\hline \multicolumn{5}{|l|}{ PAH dioxygenase } \\
\hline ISPGRLE2B & $2809-2828 \dagger$ & $45,55 \#$ & TCTATCTTCTCGTCGCTCGC & This study \\
\hline ISPGRRI3A & $2548-2564 \dagger$ & $45,50 \#$ & CGAGCGACTTCTTTCAA & This study \\
\hline \multicolumn{5}{|l|}{$\mathrm{C} 23 \mathrm{O}$} \\
\hline PS1 & $595-613 \ddagger$ & $50^{* *}$ & TCGTGSGCYTTGGTCGACA & This study \\
\hline PS2 & $702-719 \ddagger$ & $30^{* * *}$ & GACCTGATCTCCATGACC & This study \\
\hline SPH & 689-7099 & $20,50^{* * r}$ & CTGGCACGATGTTGGCCATG & This study \\
\hline $\mathrm{C} 23 \mathrm{O}$ & $765-785 \ddagger$ & $50^{* *}$ & GAAGAAGTAGATGGTCTTGCC & This study \\
\hline
\end{tabular}

${ }^{*} \mathrm{D}=\mathrm{A}+\mathrm{T}+\mathrm{G}, \mathrm{S}=\mathrm{C}+\mathrm{G}, \mathrm{Y}=\mathrm{C}+\mathrm{T}, \mathrm{W}=\mathrm{A}+\mathrm{T}, \mathrm{M}=\mathrm{A}+\mathrm{C}$.

$\dagger$ Numbered according to the published sequence of $P$. putida OUS82 PAH dioxygenase, (GenBank accession number D16629).

$\ddagger$ Numbered according to the published sequence of $P$. putida plasmid NAH7 C23O (M17159).

$\$$ Deoxyinosine nucleotides within the primers described by Wikström et al. (1996) were replaced by wobble nucleotides $(A+T+G)$.

\| Modification of the primer 23OR.

9 Numbered according to the published sequence of S. yanoikuyae B1 C23O (U23375).

\# Hybridization and washing temperatures $\left({ }^{\circ} \mathrm{C}\right)$.

** Percentage formamide in hybridization buffer. Hybridization was performed at $35^{\circ} \mathrm{C}$.

was determined using a blank reference, i.e. sterile media with PAH.

Monitoring phenanthrene degradation on solid media. Solid basal medium (DSMZ no. 457), both plain and supplemented with $0.05 \%$ salicylate, $10 \%$ trypticase soy broth or $10 \%$ brain heart infusion was coated with a crystalline layer of phenanthrene by adding $250 \mu \mathrm{l}$ of a $1 \%$ phenanthrene/acetone solution. Freshly grown bacterial colonies on R2A agar were transferred with an inoculation needle to the surface of the different phenanthrene plates after evaporation of acetone. The agar plates were incubated at $30^{\circ} \mathrm{C}$ and checked for clearing zones and increasing biomass around the areas of inoculation every $24 \mathrm{~h}$.

Determination of C230 activity. Bacterial strains were grown in $150 \mathrm{ml}$ basal medium (Kästner et al., 1994) supplemented with $0.05 \%$ phenanthrene or naphthalene to exponential phase of growth. Preparation of the crude enzyme lysate and the enzyme assay were performed as described by Hamzah \& Al-Baharna (1994), using $20 \mathrm{mM}$ potassium phosphate buffer (pH 6.8) for cell suspension and $0.05-5 \mathrm{mg}$ of the crude lysate in $750 \mu \mathrm{l} 20 \mathrm{mM}$ phosphate buffer $(\mathrm{pH} 6.8)$ with $0.5 \mathrm{nmol}$ catechol for the enzyme assay. Protein concentrations were determined by the Biuret method, using BSA as a standard. $\mathrm{C} 23 \mathrm{O}$ activity was determined by measuring the increase in absorbance at $375 \mathrm{~nm}$ due to the formation of 2-hydroxymuconic semialdehyde (molar absorption coefficient $4.4 \times 10^{4} \mathrm{M}^{-1} \mathrm{~cm}^{-1}$ ) (Nozaki et al., 1963). The absorption spectra from 230 to $450 \mathrm{~nm}$ were recorded over $3.5 \mathrm{~min}$ or, in the case of low enzyme activity over $14 \mathrm{~min}$, at periodic intervals of $30 \mathrm{~s}$ or 2 min using an Ultrospec $4000 \mathrm{UV} / \mathrm{VIS}$ spectrophotometer (Pharmacia).

Design of PCR primers and internal oligonucleotide probes. Previously published gene sequences of initial PAH dioxygenase and $\mathrm{C} 23 \mathrm{O}$ were aligned using the MacMolly Tetra 3.7 software (Sequence 17; Softgene). Four published sequences of the initial dioxygenase were aligned with sequences of three other dioxygenases; for $\mathrm{C} 23 \mathrm{O}$ gene fragments, 12 completely known sequences of $\mathrm{C} 23 \mathrm{O}$ genes were considered. Pairs of primers for PCR and internal oligonucleotide probes were selected from the conserved regions of these genes.

DNA extraction and PCR amplification. DNA was isolated and purified using standard procedures (Wilson, 1994).

About $10 \mathrm{ng}$ of isolated DNA was used for PCR. The final PCR mix contained $67 \mathrm{mM}$ Tris $/ \mathrm{HCl}$ (pH 8.8), $16.6 \mathrm{mM}$ 
Dioxygenases of polyaromatic hydrocarbon degraders

$\left(\mathrm{NH}_{4}\right)_{2} \mathrm{SO}_{4}, 0 \cdot 45 \%$ Triton X-100, 0.2 $\mathrm{mg}$ gelatin $\mathrm{ml}^{-1}, 120 \mu \mathrm{M}$ of each dNTP (Promega), $2 \mathrm{mM} \mathrm{MgCl}, 100 \mathrm{pmol}$ of each primer (synthesized by Gibco BRL) and $1 \mathrm{U}$ Taq DNA polymerase (Pharmacia Biotech). Reactions were performed in a total volume of $50 \mu \mathrm{l}$ using a Touch Down thermal cycler (Hybaid). PCR consisted of an initial denaturation step for 5 min at $94^{\circ} \mathrm{C}$, followed by 35 cycles of denaturation at $94^{\circ} \mathrm{C}$ for $15 \mathrm{~s}$, annealing at the respective temperature for each pair of primers for $30 \mathrm{~s}$ (see Table 2), extension at $72^{\circ} \mathrm{C}$ for $45 \mathrm{~s}$, and a final extension step at $72^{\circ} \mathrm{C}$ for $3 \mathrm{~min}$. The PCR mixes $(5 \mu \mathrm{l})$ were separated on a $1.5 \%$ agarose gel, stained with ethidium bromide and photographed under UV transillumination $(254 \mathrm{~nm})$.

Southern blots and hybridization of nucleic acids. The products of PCR amplification were transferred to a positively charged nylon membrane (Hybond-N+; Amersham) for hybridization with internal oligonucleotide probes using standard protocols (Sambrook et al., 1989). Southern blots were hybridized with oligonucleotides either labelled with peroxidase or labelled with $\left[\gamma^{-32} \mathrm{P}\right] \mathrm{dATP}$. Peroxidase labelling reactions were performed as described by Urdea et al. (1988). The stringency conditions were adjusted by adding different amounts of formamide (Table 2) according to each oligonucleotide. Bound probes were detected by enhanced chemiluminescence (ECL; Amersham) as described by the manufacturer.

Radioactive labelling and hybridization with oligonucleotide probes using $\left[\gamma_{-}{ }^{32} \mathrm{P}\right] \mathrm{dATP}, \mathrm{T} 4$ polynucleotide kinase (New England Biolabs) and Rapid-Hyb-buffer (Amersham) were performed as described by the manufacturer. Stringency conditions were adjusted by increasing the temperature (standard: $45^{\circ} \mathrm{C}$ ) of hybridization and by post-hybridization washing procedures (standard salt concentration: $2 \times$ SSC; $0 \cdot 1 \%$ SDS; and standard washing temperature: $45^{\circ} \mathrm{C}$ ).

\section{RESULTS AND DISCUSSION}

\section{Isolation and taxonomic affiliation of the isolated PAH degraders}

The isolation of bacteria degrading PAH was most successful with the samples originating from the municipal wastewater treatment plant. Other methods tested for isolating PAH degraders were less successful. Pure cultures isolated by an overlay technique described by Bogardt \& Hemmingsen (1992) showed no PAH degradation ability. The method described by Thiem $\&$ Fritsche (1995) using the surfactant Sapogenat T-300 as additive was not suitable for selective enrichment of PAH degraders since the detergent could be alternatively utilized as carbon and energy source. The minimal medium described by Kästner et al. (1994) was used because it allowed optimal growth of different PAHdegrading reference organisms in comparison to other minimal media tested (Weissenfels et al., 1990; Keuth \& Rehm, 1991).

Eighteen isolates degrading $\mathrm{PAH}$ were affiliated to different taxa (Table 1). Almost all the organisms could be identified at the species level. Strains of the alpha-, beta- and gamma-subclasses of Proteobacteria as well as Gram-positive bacteria with high and low DNA G +C content were isolated from the different sites. More Gram-negative organisms were isolated ( 15 out of 18 strains) and representatives of the genera Pseudomonas and Sphingomonas formed a remarkably high proportion of the isolates (Table 1).

\section{Degradation of phenathrene and naphthalene}

Results of tests in liquid medium (Table 1) showed that representatives of the same genera possessed the same abilities to degrade phenathrene and naphthalene. An exception was the Pseudomonas fluorescens strain C4, which degraded both PAHs whilst all other Pseudomonas isolates metabolized only naphthalene. It is remarkable that $\mathrm{C} 4$ was the only Pseudomonas strain isolated from soil and not from activated sludge. Isolates from the same environmental sample seemed to be more similar to each other regarding their PAH degradation potential compared with representatives of the same species but from another site.

The results obtained in liquid medium were confirmed by a test on solid medium; on this medium a Comamonas strain (G) also degraded phenanthrene and two other strains (F and B1) showed weak activity towards this carbon source, that is these isolates were generally able to utilize phenanthrene but in liquid medium it seemed to be unavailable. It is interesting that the addition of a further carbon source (salicylate, trypticase soy broth or brain heart infusion) induced the degradation of phenanthrene by most isolates. However, some contrary results were obtained, for example salicylate inhibited phenanthrene degradation by isolate $\mathrm{E}$.

On the basis of these results it could be concluded that the degradation of PAHs is regulated in a complicated manner and that isolates of the same species were differently influenced by additional carbon sources.

\section{Kinetics of phenanthrene and naphthalene degradation}

Gas chromatographic measurement of phenanthrene and naphthalene concentrations in sterile reference flasks showed that abiotic processes only caused an insignificant decrease in phenanthrene in the medium used, whilst naphthalene, being very volatile, was abiotically reduced to amounts of less than $50 \%$ of the initial value during the course of $5 \mathrm{~d}$. Phenanthrene degradation kinetics were similar when determined using isolates $\mathrm{C} 4, \mathrm{E}, \mathrm{E} 10, \mathrm{E} 3$ or $\mathrm{Y} 9$. The phenanthrene content in the medium decreased constantly. After $5 \mathrm{~d}$, approximately $60 \%$ of the initial amount was metabolized. The simultaneous increase in the optical density showed that the PAH was used as the source of carbon and energy.

The growth curves with phenanthrene of isolate $\mathrm{E}$ (Acidovorax sp.) and isolate $\mathrm{C} 4$ ( $P$. fluorescens) are shown as examples in Fig. 1(a). The degradation of naphthalene was faster for most of the isolates. After $2 \mathrm{~d}$, about $80 \%$ of the initial amount was degraded as is shown for P. fluorescens strain C4 (Fig. 1b). Optical density increased during the first $2 \mathrm{~d}$ and remained 

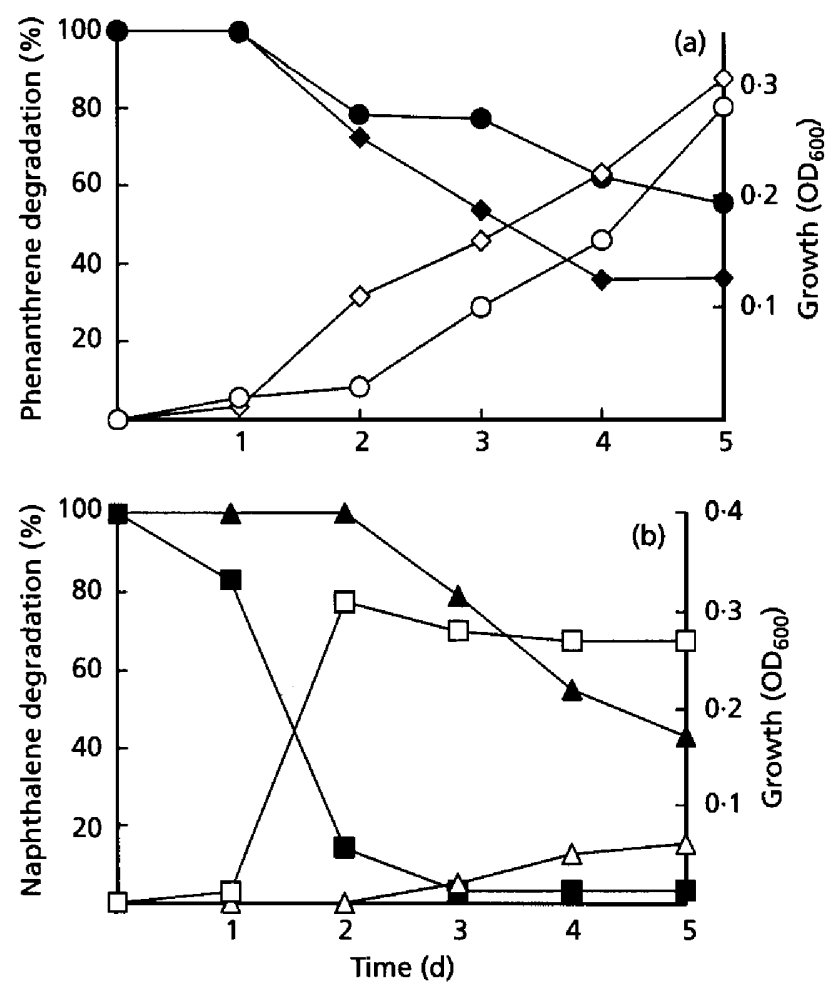

Fig. 1. Growth (open symbols) and PAH degradation (filled symbols) of various environmental isolates in mineral medium with naphthalene (a) or phenanthrene (b) as sole source of carbon and energy. PAH removal was measured gas chromatographically and was corrected for abiotic losses using a sterile control. (a) $\bigcirc, \bullet$, isolate C4 (P. fluorescens); $\diamond, \diamond$, isolate $\mathrm{E}$ (Acidovorax sp.). (b) $\square, \square$, isolate C4 (P. fluorescens); $\triangle, \Delta$, isolate B1 ( $R$. rhodochrous).

stable until the source of carbon was finally consumed. Similar results were obtained for naphthalene degradation by other Pseudomonas (F, F9, T9, A10 and L7) and Comamonas (G, H and M7) isolates.

The more rapid microbial degradation of naphthalene compared to phenanthrene could be explained by its lower recalcitrance, which correlates positively with molecular mass and negatively with aqueous water solubility (Cerniglia, 1992). The Rhodococcus rbodochrous strain B1 seemed to be an exception (Fig. 1b). No significant degradation of naphthalene was recorded during the first $2 \mathrm{~d}$. Only $60 \%$ of the initial amount was degraded within $5 \mathrm{~d}$. The optical density increased only minimally. Similar results were obtained with the second Rhodococcus isolate (G10, Rhodococcus erythropolis). The PAH degradation pathway of these two Grampositive Rhodococcus isolates seems to be regulated in a different manner to that in proteobacterial isolates.

\section{Catechol dioxygenase activity}

The enzymic conversion of catechol showed that $\mathrm{C} 23 \mathrm{Os}$ were significantly induced in cells of the two reference strains (P. putida OUS82 and S. yanoikuyae DSM 6900) and of the environmental isolates, excepting the Grampositive bacteria (isolates 3, B1 and G10). None of the strains showed catechol 1,2-dioxygenase activity. Thus meta-cleavage of catechol was most common among the environmental isolates for the lower pathway of PAH degradation. The strains of the different genera varied extremely with respect to their specific enzymic activities (Table 1). Cells of Pseudomonas species possessed the highest specific activity on average, with values between 140 and $650 \mathrm{mU}$ (mg protein) ${ }^{-1}$. Exceptions were a P. putida strain (F) with a specific activity of about $20 \mathrm{mU}$ (mg protein) ${ }^{-1}$ and a P. mendocina strain (L7) with less than $1 \mathrm{mU}$ (mg protein) $)^{-1}$. These results showed that $\mathrm{C} 23 \mathrm{O}$ specific activities in different species of the same genus could vary extremely. Specific activities of $\mathrm{C} 23 \mathrm{O}$ in the three different Sphingomonas strains were also highly heterogeneous. Isolate E3 and Y9 possessed an enzyme displaying an activity as high as the $P$. fluorescens strains. All isolates affiliated to the beta-subclass of Proteobacteria, Acidovorax spp. and Comamonas spp. possessed very low specific $\mathrm{C} 23 \mathrm{O}$ activities.

The specific activities for the Sphingomonas isolates E3 and Y9 increased during prolonged growth with phenanthrene as sole source of carbon. It is noticeable that growth with phenanthrene resulted in a higher specific activity for both reference strains than with naphthalene.

Information on $\mathrm{C} 23 \mathrm{O}$ enzymic activities with respect to utilization of monoaromatic compounds already exists. Worsey et al. (1978) reported that cells of $P$. putida $\mathrm{mt}-2$ grown in toluene had a specific $\mathrm{C} 23 \mathrm{O}$ activity of $3300 \mathrm{mU}$ (mg protein) ${ }^{-1}$, whilst Brinkmann et al. (1994) determined a C23O activity for P. putida PaW1 (pWW0) of $1360 \mathrm{mU}$ (mg protein) ${ }^{-1}$.

The wide variety of specific activities of the C23Os examined suggests heterogeneity in enzyme structure or gene regulation of the different isolates.

\section{Detection of genes encoding initial PAH dioxygenase by PCR and hybridization}

DNA sequences of different bacterial multicomponent dioxygenases are divergent with regard to comparisons of initial naphthalene dioxygenases with benzene, toluene and biphenyl dioxygenases. When comparing the DNA sequences of Pseudomonas dioxygenase large iron-sulfur subunits, the similarity of calculated sequence pair distances of $P$. putida NCIB 9816 (GenBank accession no. M23914), P. putida G7 (M83949), $P$. putida OUS82 (D16629) and $P$. aeruginosa PaK1 (D84146) PAH dioxygenases with toluene dioxygenase of $P$. putida F1 (J04996), benzene dioxygenase of $P$. putida ML2 (L04642) and biphenyl dioxygenase of $P$. putida LB400 (M86348) is between $45 \%$ and $49 \%$ (Simon et al., 1993; Kiyohara et al., 1994).

Specific primer pairs for the large iron-sulfur subunit of the PAH dioxygenases were created based on the sequence alignment. By using primers ISPGRLE1B and 


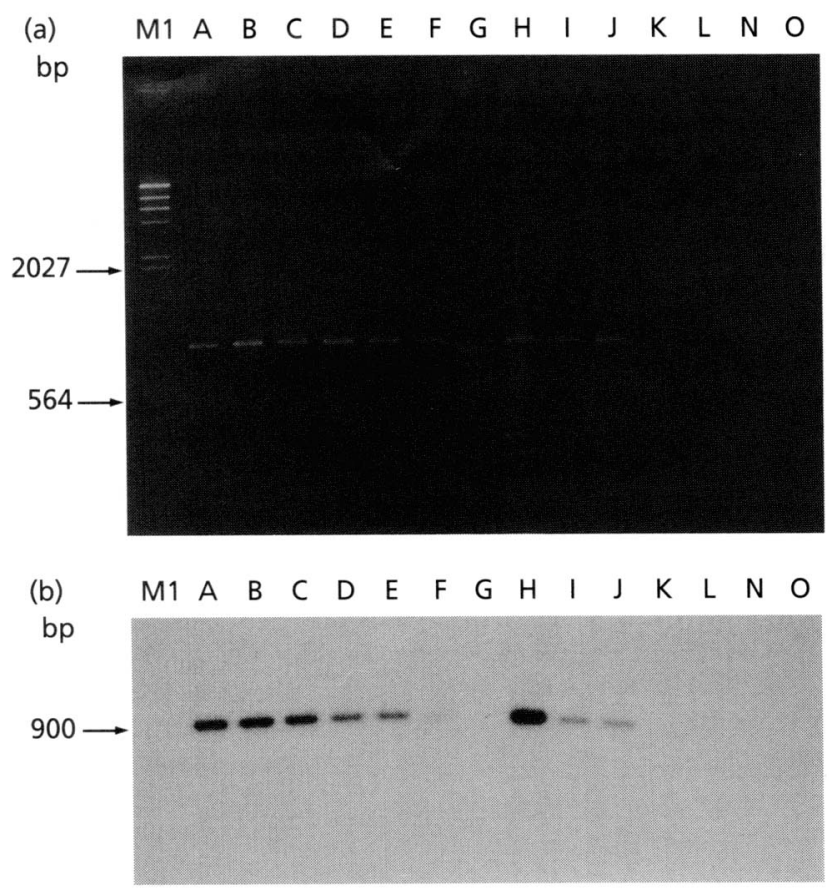

Fig. 2. Ethidium-bromide-stained $1.5 \%$ agarose gel (a) showing PCR amplification products obtained with genomic DNA extracted from various reference strains and environmental isolates using primer pairs ISPGRLE1B/ISPGRRI1B and the corresponding Southern blot (b). Lanes: M1, lambda HindIII marker; $\mathrm{A}$, isolate $\mathrm{F}(P$. putida); $\mathrm{B}$, isolate $\mathrm{A} 10$ ( $P$. fluorescens); $C$, isolate C4 ( $P$. fluorescens); $D$, isolate F9 ( $P$. fluorescens); $E$, isolate $\mathrm{H9}$ ( $P$. fluorescens); $\mathrm{F}$, isolate T9 ( $P$. fluorescens); $\mathrm{G}$, isolate L7 ( $P$. mendocina); H, $P$. stutzeri AN11; I, $P$. putida OUS82; J, P. putida NCIB 9816; K, P. putida F1; L, P. putida KT2440; N, E. coli SURE; O, no DNA control.

ISPGRRI1B (Table 2) amplification products of $0.9 \mathrm{~kb}$ could be generated for reference strains (positive controls $P$. putida OUS82 and NCIB 9816), all naphthalene- and phenanthrene-degrading isolates belonging to the genus Pseudomonas, F (P. putida), A10, C4, F9, H9, T9 (all P. fluorescens) and P. stutzeri AN11. Isolate L7 ( $P$. mendocina) showed a weak but smallersized amplicon $(0.83 \mathrm{~kb}$; Fig. 2a). However, isolated strains not belonging to the genus Pseudomonas, but able to degrade naphthalene and/or phenanthrene, had no significant PCR amplicon pattern. In this context it should be mentioned that $E$. coligenerated amplification products $( \pm 2.0$ and $\pm 1.1 \mathrm{~kb})$, under low-stringency conditions but the nonspecific nature could be determined by sequencing.

To provide a second criterion for specifying the detection of PAH dioxygenase genes in bacterial communities, different oligonucleotide probes located in the internal region of the amplicons, were designed (Table 2). Hybridization signals even under high-stringency conditions $\left(55^{\circ} \mathrm{C}\right)$ were obtained for isolated $P$. fluorescens strains (isolates A10, C4, F9, H9 and T9), P. putida (isolate $F$ ) and the positive reference strains, $P$. putida NCIB 9816 and OUS82, using the radioactively labelled oligonucleotide probes ISPGRLE2B and ISPGRRI3A (Fig. 2b). Weak hybridization signals were obtained for P. stutzeri AN11 PCR amplicons under this stringency condition only for probe ISPGRLE2B. This result can be explained by the fact that there is a slight divergence in the DNA sequence between $P$. stutzeri AN11 and P. fluorescens and P. putida (results not shown). Isolate L7 (P. mendocina) showed no signal under various hybridization conditions, though a smaller weak PCR amplicon could be detected in ethidium-bromide-stained agarose gels (Fig. 2a). These results lead to the conclusion that Pseudomonas PAH dioxygenases are quite different at the DNA level without affecting the active site of the large iron-sulfur subunit of multicomponent PAH dioxygenases. It is necessary to gain more sequence information for different strains of the genus Pseudomonas to establish a universal Pseudomonas PAH dioxygenase PCR and hybridization detection system. With the present method, it is possible to detect a specific allelle of PAH dioxygenase large iron-sulfur subunit from $P$. putida, $P$. fluorescens and $P$. stutzeri.

\section{Detection of genes encoding C230 by PCR and hybridization}

Published nucleotide sequences of $\mathrm{C} 23 \mathrm{O}$ were aligned and similarity distances were calculated pairwise. The C23O sequences of different Pseudomonas strains (P. aeruginosa JI104, GenBank accession no. X60740; P. putida CF600, M33263; P. putida P 35X, X77856; P. putida pDK1, M65205; P. putida strain H, X80765; P. putida pWW0, M64747; P. putida NAH, M17159; and Pseudomonas sp. IC, UO1825) displayed similar values between $75 \%$ and more than $95 \%$. These clusters of highly similar sequences were further designated as the 'Pseudomonas group'. Sequences of two Sphingomonas strains have also been published. C23O DNA sequences of Sphingomonas sp. HV3 (L10655) and S. yanoikuyae B1 (U23375) are $76.5 \%$ similar to each other ('Sphingomonas group'). The similarities to the sequences of the 'Pseudomonas group' amounts to about $50 \%$.

$\mathrm{C} 23 \mathrm{O}$ sequences from bacteria belonging to other genera, such as Ralstonia (R. pickettii, formerly Pseudomonas pickettii (U20258), R. eutropha, formerly Alcaligenes eutrophus JMP (52415)), Rhodococcus (R. rhodochrous CTM, X69504), R. rhodochrous NCIB 13064 (L77225) and Bacillus (B. stearothermophilus FDTP-3, X67860) are rather heterogeneous. These sequences are not very similar to each other or to the 'Pseudomonas group' and 'Sphingomonas group'. For this reason it was not likely that all $\mathrm{C} 23 \mathrm{O}$ genes could be detected by one universal pair of primers.

The application of the PCR primers 23OF/23OR (Wikström et al., 1996) resulted in detection of C23O sequences of all reference strains and isolates belonging to the 'Pseudomonas group' and 'Sphingomonas group' (Table 3). However, the other isolates which have an active $\mathrm{C} 23 \mathrm{O}$ detected by the enzymic test showed no 
Table 3. Results of PCR amplification and hybridization of initial dioxygenase and C230 gene sequences of reference strains and environmental isolates

\begin{tabular}{|c|c|c|c|c|c|c|c|c|c|c|}
\hline \multirow[t]{2}{*}{ Bacterial strain } & \multicolumn{4}{|c|}{ PCR product } & \multicolumn{6}{|c|}{ Hybridization with probe } \\
\hline & $\begin{array}{l}\text { ISPGRLE1B } \\
\text { ISPGRRI1B }\end{array}$ & $\begin{array}{l}23 \mathrm{OF} \\
23 \mathrm{OR}\end{array}$ & $\begin{array}{l}\text { PSCA23St } \\
\text { PSCA23End }\end{array}$ & $\begin{array}{c}\text { SPHCA23St } \\
\text { 23OR }\end{array}$ & $\begin{array}{c}\text { ISPGR } \\
\text { LE2B }\end{array}$ & $\begin{array}{c}\text { ISPGR } \\
\text { RI3A }\end{array}$ & PS1 & PS2 & SPH & $\mathrm{C} 23 \mathrm{O}$ \\
\hline \multicolumn{11}{|l|}{ Reference strains } \\
\hline P. putida OUS82 & + & + & + & - & + & ++ & + & + & - & + \\
\hline P. putida NCIB 9816 & + & + & + & - & + & + & + & + & - & + \\
\hline P. stutzeri AN11 & + & + & + & - & + & + & + & + & - & + \\
\hline S. paucimobilis BA2 & - & + & - & + & $\mathrm{NA}$ & $\mathrm{NA}$ & - & - & $t^{*}$ & - \\
\hline S. yanoikuyae DSM 6900 & - & + & - & + & $\mathrm{NA}$ & NA & - & - & + & + \\
\hline P. putida KT2440 & - & - & - & - & NA & $\mathrm{NA}$ & NA & NA & NA & NA \\
\hline P. putida F1 & - & ND & + & - & $\mathrm{NA}$ & $\mathrm{NA}$ & - & + & - & + \\
\hline E. coli SURE & - & - & - & - & NA & $\mathrm{NA}$ & $\mathrm{NA}$ & $\mathrm{NA}$ & NA & NA \\
\hline \multicolumn{11}{|l|}{ Environmental isolates } \\
\hline $\begin{array}{l}\text { Sphingomonas sp. } \\
\text { (isolate Y9) }\end{array}$ & - & + & - & + & $\mathrm{NA}$ & $\mathrm{NA}$ & - & - & + & + \\
\hline $\begin{array}{l}\text { Sphingomonas sp. } \\
\text { (isolate E3) }\end{array}$ & - & + & - & + & NA & $\mathrm{NA}$ & - & - & + & + \\
\hline Acidovorax sp. (isolate E) & - & - & - & - & $\mathrm{NA}$ & $\mathrm{NA}$ & $\mathrm{NA}$ & NA & $\mathrm{NA}$ & NA \\
\hline Acidovorax sp. (isolate E10) & - & - & - & - & NA & $\mathrm{NA}$ & NA & NA & $\mathrm{NA}$ & NA \\
\hline Acidovorax sp. (isolate V10) & - & - & - & - & $\mathrm{NA}$ & $\mathrm{NA}$ & $\mathrm{NA}$ & $\mathrm{NA}$ & NA & NA \\
\hline C. testosteroni (isolate G) & - & - & - & - & NA & NA & NA & $\mathrm{NA}$ & NA & NA \\
\hline C. testosteroni (isolate $\mathrm{H}$ ) & - & - & - & - & $\mathrm{NA}$ & NA & $\mathrm{NA}$ & NA & NA & NA \\
\hline C. terrigena (isolate M7) & - & - & - & - & $\mathrm{NA}$ & NA & NA & NA & $\mathrm{NA}$ & NA \\
\hline P. fluorescens (isolate A10) & + & + & + & - & - & + & + & + & - & + \\
\hline P. fluorescens (isolate F9) & + & + & + & - & + & + & + & + & - & + \\
\hline P. fluorescens (isolate $\mathrm{H} 9$ ) & + & + & + & - & + & + & + & + & - & + \\
\hline P. fluorescens (isolate T9) & + & + & + & - & + & + & + & + & - & + \\
\hline P. fluorescens (isolate C4) & + & + & + & - & + & + & + & + & - & + \\
\hline P. mendocina (isolate L7) & - & + & + & - & NA & $\mathrm{NA}$ & - & + & - & + \\
\hline P. putida (isolate F) & + & + & + & - & + & + & + & + & - & + \\
\hline R. rhodochrous (isolate B1) & - & - & - & - & $\mathrm{NA}$ & NA & NA & NA & NA & NA \\
\hline R. erythropolis (isolate G10) & - & - & - & - & NA & NA & $\mathrm{NA}$ & $\mathrm{NA}$ & NA & NA \\
\hline Paenibacillus sp. (isolate 3) & - & - & - & - & NA & NA & $\mathrm{NA}$ & $\mathrm{NA}$ & NA & NA \\
\hline
\end{tabular}

NA, No amplification product for hybridization test obtained, see columns $2-5$.

ND, Not determined.

"Showed only a weak hybridization signal using relaxed conditions of hybridization ( $20 \%$ formamide).

amplification products, even using relaxed conditions for primer annealing $\left(60^{\circ} \mathrm{C}\right)$ (data not shown).

On account of the high homology of $\mathrm{C} 23 \mathrm{O}$ sequences of different Pseudomonas strains on the one hand and Sphingomonas strains on the other, it was checked if it was possible to detect the $\mathrm{C} 23 \mathrm{O}$ genes of these genera specifically by PCR. Two specific pairs of primers were developed for this purpose (Table 2). The primers PSCA23St and PSCA23End were designed to detect representatives of the 'Pseudomonas group'. SPHCA23St was specifically designed to detect C23O sequences of the 'Sphingomonas group' in combination with primer $23 \mathrm{OR}$. The resulting amplicons have a length of approximately $900 \mathrm{bp}$ and therefore make up nearly the complete gene. Table 3 shows the results of the PCR tests. Application of PSCA23St/PSCA23End resulted in the expected $900 \mathrm{bp}$ fragment for the reference strains $P$. putida OUS82 and $P$. putida NCIB 9816, as well as for all Pseudomonas isolates (Fig. 3a). P. putida F1 and P. mendocina (isolate L7) showed only weak amplification products. $P$. putida KT2440 lacking $\mathrm{C} 23 \mathrm{O}$ and all other isolates yielded no PCR products. Using the primers SPHCA23St and 23OR, only the Sphingomonas isolates (Y9 and E3) and the respective reference strains (S. paucimobilis BA2 and S. yanoikuyae DSM 6900) showed an amplification product of the predicted size (Fig. 4a). The results clearly demonstrated that the PCR-based approach with these primers is suitable for specific detection of Pseudomonas and Sphingomonas C23O gene sequences.

Oligonucleotide probes were designed for further confirmation of the identity of the PCR amplicons, targeting 
(a)

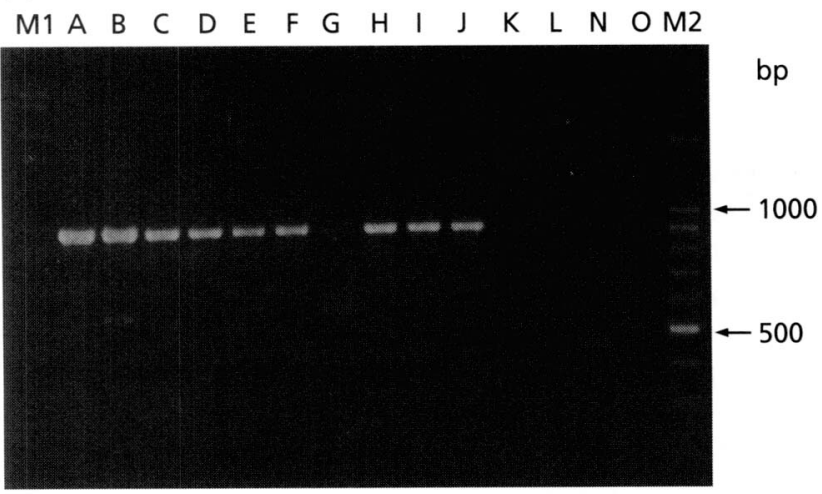

(b)

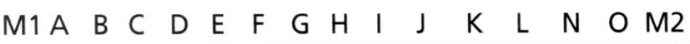

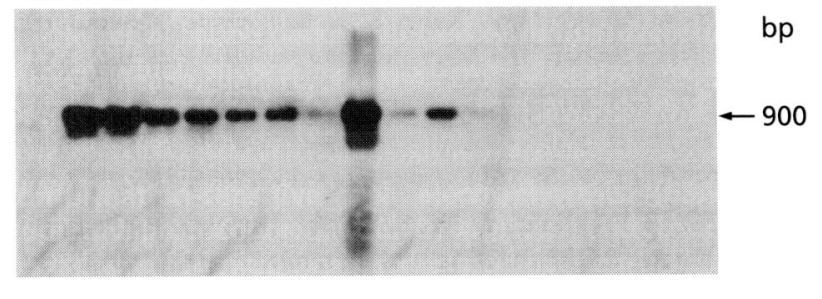

Fig. 3. Ethidium-bromide-stained $1.5 \%$ agarose gel (a) showing PCR amplification products obtained with genomic DNA extracted from various reference strains and environmental isolates using primer pair PSCA235t/PSCA23End and the corresponding Southern blot (b). Lanes: $M 1$, lambda EcoR I/HindIII marker; A, isolate $F(P$. putida); $B$, isolate A10 $(P$. fluorescens); $C$, isolate C4 ( $P$. fluorescens): $D$, isolate F9 ( $P$. fluorescens); $\mathrm{E}$, isolate $\mathrm{H} 9$ ( $P$. fluorescens); $\mathrm{F}_{\text {, isolate } \mathrm{T}}$ (P. fluorescens); G, isolate L7 (P. mendocina); H, P. stutzeri AN11; I, $P$. putida OUS82; J, $P$. putida NCIB 9816; K, $P$. putida F1; $L$, $P$. putida KT2440; N, E. coli SURE, O, no DNA control; M2, 100 bp ladder.

internal regions (Table 2). The probe PS1 hybridized specifically with amplification products of the Pseudomonas strains with stringent hybridization conditions $(50 \%, v / v$, formamide). Only the weak PCR products of $P$. putid $a \mathrm{~F} 1$ and L7 did not hybridize with this probe, even at relaxed hybridization conditions $(20 \%, v / v$, formamide). However, hybridization signals were obtained for all Pseudomonas strains using the second Pseudomonas-specific oligonucleotide probe PS2 (Fig. $3 \mathrm{~b})$. The 'Sphingomonas group' probe SPH hybridized specifically with amplification products of the different Sphingomonas strains. Only the PCR amplicon of $S$. paucimobilis BA2 did not hybridize (Fig. 4b). When hybridized at a formamide concentration of $20 \%$, the PCR product of $S$. paucimobilis BA2 also showed a weak hybridization signal. In comparison to these specific probes, a second general probe, $\mathrm{C} 23 \mathrm{O}$, hybridized with PCR products of all Pseudomonas strains as well as all Sphingomonas strains, except again S. paucimobilis BA2.

Based on the results of PCR and hybridization, it could be suggested that $\mathrm{C} 23 \mathrm{O}$ genes of the different environmental Pseudomonas and Sphingomonas spp. isolates clustered with their respective sequence group. By (a)
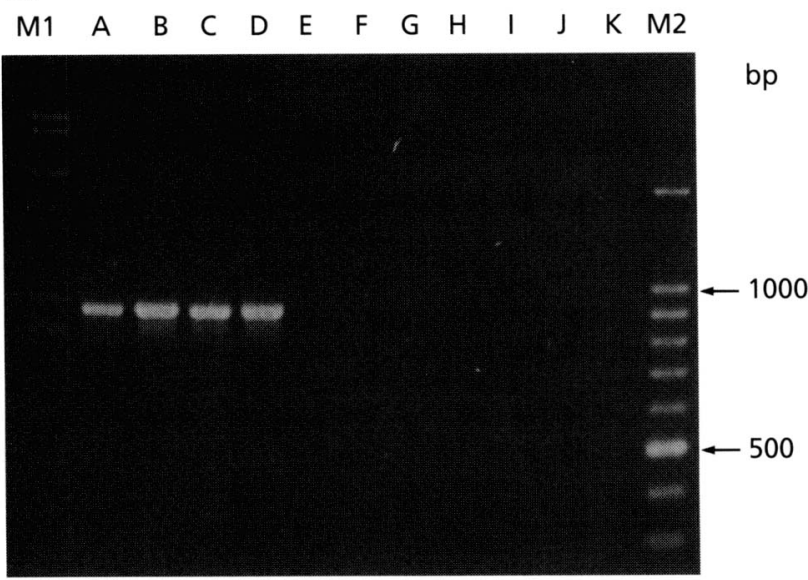

(b)

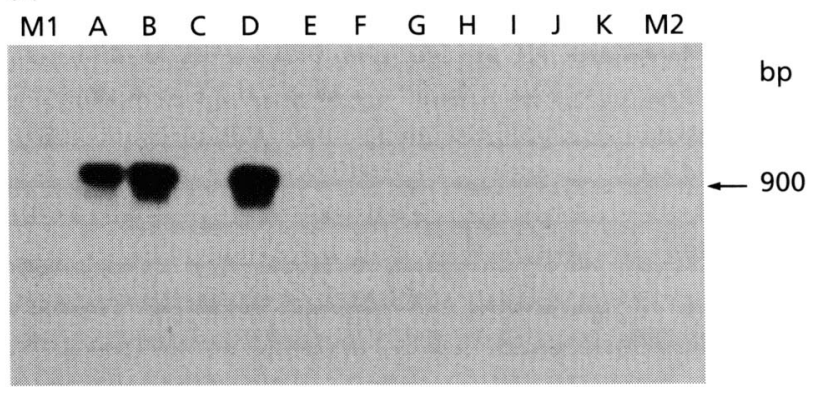

Fig. 4. Ethidium-bromide-stained $1.5 \%$ agarose gel (a) showing PCR amplification products obtained with genomic DNA extracted from various reference strains and environmental isolates using the primer pair SPHCA23St/23OR and the corresponding Southern blot (b). Lanes: M1, lambda EcoR VHindlll marker; A, isolate E3 (Sphingomonas sp.); $B$, isolate Y9 (Sphingomonas sp.): C, $S$. paucimobilis BA2; D, $S$. yanoikuyae DSM 6900; $E$, isolate A10 (P. fluorescens); $F$, $P$. putida OUS82; G, $P$. putida NCIB 9816; $H$, $P$. putida $F 1 ; I$, P. putida KT2440; J, E. coli SURE; K, no DNA control; M2, 100 bp ladder.

a general PCR step and subsequent hybridization' with the individual Pseudomonas and Sphingomonas gene probes PS1/PS2 or SPH, or alternatively, by a PCRbased approach with Pseudomonas- and Sphingomonasspecific primers, it is possible to specifically detect the presence of $\mathrm{C} 23 \mathrm{O}$ sequences of these genera. Further sequence analysis should promote optimal probe design and it should, for example, be possible to develop a probe for sphingomonads also recording the S. paucimobilis BA2 gene.

\section{Conclusions}

The isolation of bacteria degrading PAH was most successful with the method of Kästner et al. (1994). Bacteria with PAH degradation abilities were present in the investigated habitats independent of the extent of PAH contamination. The majority of isolates were affiliated to the genera Pseudomonas and Sphingomonas, but it has to be considered that the selected 
isolation strategy may have favoured Pseudomonas and Sphingomonas strains. The $\mathrm{C} 23 \mathrm{O}$ test established high enzyme activities for most representatives of these two genera. The development of sets of primers and internal oligonucleotides allowed the specific detection of the genes of initial $\mathrm{PAH}$ dioxygenase and $\mathrm{C} 23 \mathrm{O}$ for members of these two genera. However, there may still be a potential for false negative results wherein catabolic genes involved in the degradation of PAHs (that lack DNA sequence homology to the primers and/or probes) are not detected. A verification of the method with PAHdegrading pseudomonads and sphingomonads from a diversity of other sites is still necessary. It was not possible to detect further PAH degraders belonging to the genera Comamonas and Acidovorax using this approach because the catabolic gene sequences seem to be heterogeneous compared with Pseudomonas and Sphingomonas sequences. To use these as a detection system for PAH degradation potential at the DNA level, the development of an enlarged set of primers and probes, founded on new sequence information, is necessary.

\section{ACKNOWLEDGEMENTS}

This study was supported by grants from the Deutsche Forschungsgemeinschaft (Ka 875/4-1 and Sta 245/6-1). We thank H. Kiyohara, M. J. Simon, M. Kästner and D. T. Gibson for providing strains, and are indebted to K. Grebing for excellent technical assistance. We also acknowledge R. Bensmann for careful reading of the manuscript.

\section{REFERENCES}

Amann, R. I., Krumholz, L. \& Stahl, D. A. (1990). Fluorescentoligonucleotide probing of whole cells for determinative, phylogenetic and environmental studies in microbiology. $J$ Bacteriol $172,762-770$.

Amann, R., Ludwig, W., Schulze, R., Spring, S., Moore, E. \& Schleifer, K.-H. (1996). rRNA-targeted oligonucleotide probes for the identification of genuine and former pseudomonads. Syst Appl Microbiol 19, 501-509.

Bartilson, M. \& Shingler, V. (1989). Nucleotide sequence and expression of the catechol 2,3-dioxygenase-encoding gene of phenol-catabolizing Pseudomonas CF600. Gene 85, 233-238.

Benjamin, R. C., Voss, J. A. \& Kunz, D. A. (1991). Nucleotide sequence of $x y / \mathrm{E}$ from the TOL pPDK1 plasmid and structural comparison with isofunctional catechol 2,3-dioxygenase genes from TOL pWW0 and NAH7. J Bacteriol 173, 2724-2728.

Bogardt, A. H. \& Hemmingsen, B. B. (1992). Enumeration of phenanthrene-degrading bacteria by an overlay technique and its use in evaluation of petroleum-contaminated sites. Appl Environ Microbiol 58, 2579-2582.

Brinkmann, U., Ramos, J. L. \& Reineke, W. (1994). Loss of the TOL meta-cleavage pathway functions of Pseudomonas putida strain PaW1 ( $\mathrm{pWW}$ ) during growth on toluene. J Basic Microbiol 34, 303-309.

Candidus, S., van Pee, K.-H. \& Lingens, F. (1994). The catechol 2,3dioxygenase gene of R hodococcus rbodochrous CTM : nucleotide sequence, comparison with isofunctional dioxygenases and evidence for an active-site histidine. Microbiology 140, 321-330.
Carrington, B., Lowe, A., Shaw, L. E. \& Williams, P. A. (1994). The lower pathway operon for benzoate catabolism in biphenylutilizing Pseudomonas sp. strain IC and the nucleotide sequence of the $b p h E$ gene for catechol 2,3-dioxygenase. Microbiology 140 , 499-508.

Cerniglia, C. E. (1984). Microbial transformation of aromatic hydrocarbons. In Petroleum Microbiology, pp. 99-128. Edited by R. M. Atlas. New York: Macmillan.

Cerniglia, C. E. (1992). Biodegradation of polycyclic aromatic hydrocarbons. Biodegradation 3, 351-368.

Cerniglia, C. E. \& Heitkamp, M. A. (1990). Polycyclic aromatic hydrocarbon degradation by Mycobacterium. Methods Enzymol 188, 148-153.

Doetsch, R. N. (1981). Determinative methods in light microscopy. In Manual of Methods for General Microbiology, pp. 21-33. Edited by P. Gerhardt, R. G. E. Murray, R. N. Costilow, E. W. Nester, W. A. Wood, N. R. Krieg \& E. B. Phillips. Washington, DC: American Society for Microbiology.

Ensley, B. D., Gibson, D. T. \& Laborde, A. L. (1982). Oxidation of naphthalene by a multicomponent enzyme system from $P$ seudomonas sp. strain NCIB 9816. J Bacteriol 149, 948-954.

Foght, J. M. \& Westiake, D. W. S. (1988). Degradation of polycyclic aromatic hydrocarbons and aromatic heterocycles by a Pseudomonas species. Can J Microbiol 34, 1135-1141.

Franklin, F. C., Bagdasarian, H. M., Bagdasarian, M. M. \& Timmis, K. N. (1981). Molecular and functional analysis of the TOL plasmid $\mathrm{pWWO}$ from Pseudomonas putida and cloning of genes for the entire regulated aromatic ring meta cleavage pathway. Proc Natl Acad Sci 78, 7458-7462.

Ghosal, D., You, I. S. \& Gunsalus, I. C. (1987). Nucleotide sequence and expression of gene nabH of plasmid NAH7 and homology with gene $x y / \mathrm{E}$ of TOL $\mathrm{pWW}$. Gene 55, 19-28.

Gibson, D. T., Roberts, R. L., Wells, M. C. \& Kobal, V. M. (1973). Oxidation of biphenyl by a Beijerinckia species. Biochem Biophys Res Commun 50, 211-219.

Hamzah, R. Y. \& Al-Baharna, B. S. (1994). Catechol ring-cleavage in Pseudomonas cepacia: the simultaneous induction of ortho and meta pathways. Appl Microbiol Biotechnol 41, 250-256.

Harayama, S., Rekik, M., Bairoch, A, Neidle, E. L. \& Ornston, L. N. (1991). Potential DNA slippage structures acquired during evolutionary divergence of Acinetobacter calcoaceticus chromosomal benABC and Pseudomonas putida TOL pWWO plasmid $x y l \mathrm{XYZ}$, genes encoding benzoate dioxygenase. J Bacteriol 173, $7540-7548$.

Herrmann, H., Mueller, C., Schmidt, I., Mahnke, J., Petruschka, L. \& Hahnke, K. (1995). Localization and organization of the phenol degradation gene of Pseudomonas putida strain H. Mol Gen Genet 247, 240-246.

Houghton, J. E. \& Shanley, M. S. (1994). Catabolic potential of pseudomonads: regulatory perspective. In: Biological Degradation and Bioremediation of Toxic Chemicals, pp. 11-32. Edited by G. R. Chaudhry. Portland, OR: Dioscorides Press.

Johnsen, K., Andersen, S. \& Jacobsen, C. S. (1996). Phenotypic and genotypic characterization of phenanthrene-degrading fluorescent Pseudomonas biovars. Appl Environ Microbiol 62, 3818-3825.

Joshi, B. \& Walia, S. (1996). PCR amplification of catechol 2,3 dioxygenase gene sequences from naturally occuring hydrocarbon degrading bacteria isolated from petroleum hydrocarbon contaminated groundwater. FEMS Microb Ecol 19, 5-15. 
Kabisch, M. \& Fortnagel, P. (1990). Nucleotide sequence of metapyrocatechase I (catechol 2,3-oxygenase I) gene $m c p$ I from Alcaligenes eutrophus JMP222. Nucleic Acid Res 18, 3405-3406.

Kămpfer, P., Steiof, M. \& Dott, W. (1991). Microbiological characterization of a fuel-oil contaminated site including numerical identification of heterotrophic water and soil bacteria. Microb Ecol 21, 227-251.

Kămpfer, P., Erhart, R., Beimfohr, C., Böhringer, J., Wagner, M. \& Amann, R. (1996). Characterization of bacterial communities from activated sludge: culture-dependent numerical identification versus in situ identification using group- and genus-specific rRNAtargeted oligonucleotide probes. Microb Ecol 32, 101-121.

Kästner, M., Breuer-Jammali, M. \& Mahro, B. (1994). Enumeration and characterisation of the soil microflora from hydrocarboncontaminated soil sites able to mineralize polycyclic aromatic hydrocarbons (PAH). Appl Microbiol Biotechnol 41, 267-273.

Keil, H., Lebens, M. R. \& Williams, P. A. (1985). TOL plasmid pWW15 contains two nonhomologous, independently regulated catechol 2,3-oxygenase genes. J Bacteriol 163, 248-255.

Keuth, S. \& Rehm, H.-J. (1991). Biodegradation of phenanthrene by Arthrobacter polychromogenes isolated from a contaminated soil. Appl Microbiol Biotechnol 34, 804-808.

Kim, E. \& Zylstra, G. J. (1995). Molecular and biochemical characterization of two meta-cleavage dioxygenases involved in biphenyl and $m$-xylene degradation by Beijerinckia sp. strain B1. J Bacteriol 177, 3095-3103.

Kiyohara, H., Torigoe, S., Kaida, N., Asaki, T., lida, T., Hayashi, H. \& Takizawa, N. (1994). Cloning and characterization of a chromosomal gene cluster, $p a h$, that encodes the upper pathway for phenanthrene and naphthalene utilisation by Pseudomonas putida OUS82. J Bacteriol 176, 2439-2443.

Kukor, J. J. \& Olsen, R. H. (1996). Catechol 2,3-dioxygenase functional in oxygen-limited (hypoxic) environments. Appl Environ Microbiol 62, 1728-1740.

Manz, W., Amann, R., Ludwig, W., Wagner, M. \& Schleifer, K. H. (1992). Phylogenetic oligodeoxynucleotide probes for the major subclasses of Proteobacteria: problems and solutions. Syst Appl Microbiol 15, 593-600.

Moon, J., Chang, H., Min, K. R. \& Kim, Y. (1995). Cloning and sequencing of the catechol 2,3-dioxygenase gene of Alcaligenes sp. KF711. Biochem Biophys Res Commun 208, 943-949.

Ng. L. C., Shingler, V., Sze, C. C. \& Poh, C. L. (1994). Cloning and sequences of the first eight genes of chromosomally encoded (methyl) phenol degradation pathway from Pseudomonas putida P35X. Gene 151, 29-36.

Nozaki, M., Kagamiyama, H. \& Hayaishi, O. (1963). Metapyrocatechase. I. Purification, crystallization and some properties. Biochem Z 338, 582-590.

Roller, C., Wagner, M., Amann, R., Ludwig, W. \& Schleifer, K.-H. (1994). In situ probing of Gram-positive bacteria with high DNA $\mathrm{G}+\mathrm{C}$ content using $23 \mathrm{~S}$ rRNA-targeted oligonucleotides. Microbiology 140, 2849-2858.

Sambrook, J., Fritsch, E. F. \& Maniatis, T. (1989). Molecular Cloning: a Laboratory Manual, 2nd edn. Cold Spring Harbor, NY: Cold Spring Harbor Laboratory.
Schleifer, K.-H., Amann, R., Ludwig, W., Rothemund, C., Springer, N. \& Dorn, S. (1992). Nucleic acid probes for the identification and in situ detection of pseudomonads. In: Pseudomonas: Molecular Biology and Biotechnology, pp. 127-134. Edited by E. Galli, S. Silver \& B. Witholt. Washington, DC: American Society for Microbiology.

Simon, M. J., Osslund, T. D., Saunders, R. \& 7 other authors (1993). Sequences of genes encoding naphthalene dioxygenase in Pseudomonas putida strains G7 and NCIB 9816-4. Gene 127, 31-37.

Stahl, D. A., Devereux, R., Amann, R. I., Flesher, B., Lin, C. \& Stromley, 1. (1989). Ribosomal RNA based studies of natural microbial diversity and ecology. In Recent Advances in Microbial Ecology, pp. 669-673. Edited by T. Hattoni, Y. Maruyama, R. Morita \& A. Uchida. Tokyo: Japan Scientific Socieries Press.

Takizawa, N., Kaida, N., Torigoe, S., Moritani, T., Sawada, T., Satoh, S. \& Kiyohara, H. (1994). Identification and characterization of genes encoding polycyclic aromatic hydrocarbon dioxygenase and polycyclic aromatic hydrocarbon dihydrodiol dehydogenase in Pseudomonas putida OUS82. J Bacteriol 176, 2444-2449.

Thiem, A. \& Fritsche, C. (1995). Utilization of solubilized and crystalline mixtures of polycyclic aromatic hydrocarbons by a Mycobacterium sp. Appl Microbiol Biotechnol 42, 964-968.

Urdea, M. S., Warner, B. D., Running, I. A., Stempien, M., Clyne, J. \& Horn, T. (1988). A comparison of non-radioisotopic hybridization assay methods using fluorescent, chemiluminescent and enzyme labeled synthetic oligodeoxyribonucleotide probes. Nucleic Acid Res 16, 4937-4956.

Weissenfels, W. D., Beyer, M. \& Klein, J. (1990). Degradation of phenanthrene, fluorene and fluoranthene by pure bacterial cultures. Appl Microbiol Biotechnol 32, 479-484.

Wikström, P., Wiklund, A., Anderson, A. C. \& Forsman, M. (1996). DNA recovery and PCR quantification of catechol 2,3dioxygenase genes from different soil types. J Biotechnol 52, $107-120$.

Williams, P. A. \& Sayers, J. R. (1994). The evolution of pathways for aromatic hydrocarbon oxidation in Pseudomonas. Biodegradation 5, 195-217.

Wilson, K. (1994). Preparation of genomic DNA from bacteria. In Current Protocols in Molecular Biology, pp. 2.4.1-2.4.5. Edited by V. B. Chanda. New York: Wiley.

Worsey, M. J., Franklin, F. C. \& Williams, P. A. (1978). Regulation of the degradative pathway enzymes coded for by the TOL plasmid (pWW0) from Pseudomonas putida mt-2. J Bacteriol 134, $757-764$.

Yrjälä, K., Paulin, L., Kilpi, S. \& Romantschuk, M. (1994). Cloning of $c m p \mathrm{E}$, a plasmid borne catechol 2,3-dioxygenase-encoding gene from the aromatic- and chloroaromatic-degrading Pseudomonas sp. HV3. Gene 138, 119-121.

Zylstra, G. J. \& Gibson, D. T. (1989). Toluene degradation by Pseudomonas putida F1. J Biol Chem 264, 14940-14946.

Received 26 October 1998; revised 26 February 1999; accepted 8 March 1999. 